Treasurer: James Stimson, University of North Carolina

The newly elected members of the Council, APSA's governing body, are: Randall Calvert, Washington University; William Galston, University of Maryland; Edmond Keller, University of California, Los Angeles; Gary King, Harvard University; Atul Kohli, Princeton University; David Rayside, University of Toronto; Christine Maric Sierra, University of New Mexico; and Sven Stcinmo, University of Colorado.

\section{Council Business in Atlanta}

At its September 1 mecting in Atlanta, the APSA Council

- Approved a joint membership arrangement with the American Association of Political Consultants (see related story).

- Extended the life of the Ad Hoc Committee on Political Science and the National Science Foundation to April 2000.

- Ratified the Standing and Award Committee appointments of President-Elect Robert Keohane (to be published in the March issue of $P S$ ).

- Amended and consented to the balanced budget for FY 2000-01 presented by Treasurer Timothy Cook.

- Received an interim report from Charles Johnson, chair of the Committee on Education and Professional Development, asking for Council involvement in the development of recommendations to departments to address the changing job market and the need for further professional development of graduate students and new faculty.

- Authorized a draw down of up to $\$ 60,000$ from APSA's operating

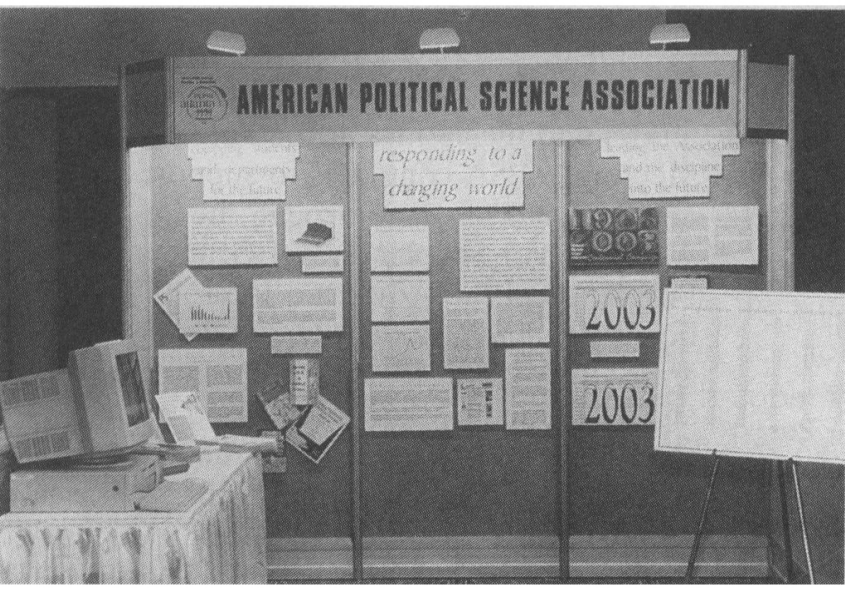

The APSA exhibit booth highlighted the important programs and activities the Association develops and maintains for its members.
Robert Hauck-and the success of the general Campaign and the special initiatives, including three new ones for the Jewel PrestageRichard Fenno Endowment for the Ralph Bunche Summer Institute, the Ostrom-Awan Endowment for civic education, and the Walter Beach Endowment for graduate student travel grants. fund to appeal the Association's real estate tax status in the District of Columbia should the Administrative Committee decide that proceeding in the litigation would be prudent.

- Approved the preregistration fee schedule for the $2000 \mathrm{An}$ nual Meeting and established a standing 5\% annual increase thereafter in lieu of triennial increases.

- Received the final report of Pippa Norris, chair of the Ad Hoc Committee on Technology, concerning the relaunch of APSA's web site and new electronic services offered by APSA.

- Applauded the work of the Centennial Campaign leadersespecially that of Dale Rogers Marshall, Jack Peltason, and

\section{Graduate Students Attend Meeting with APSA Assistance}

In a continuing effort to assist graduate students wishing to participate in the Annual Meeting, the Association awarded 32 Advanced Graduate Student Travel Grants for its 1999 meeting in Atlanta. Funded by APSA, winners were selected from a pool of over 125 applicants, all of whom were scheduled to present a paper or poster.

Since the grants were first awarded in 1994, nearly 150 doctoral students from the United States have been funded. The number of applications submitted for consideration has risen nearly $50 \%$. At the 1999 meeting in Atlanta, graduate students delivered papers on approximately 700 panels and roundtables and were well represented among the 400 scholars presenting papers.

As the number of applicants grows and the level of departmental support available to graduate students decreases, the Association is finding it increasingly difficult to meet its goal of ensuring maximum student participation. Contributions to the travel grant fund are welcome from Organized Sections, Related Groups, and individual members. If you are interesting in contributing, please contact Sean Twombly at (202) 483-2512 or twombly@apsanet.org. 